\title{
Neonatal Sepsis and its Associated Risk Factors in Albatool Teaching hospital / Diyala / Iraq
}

\author{
Douaa Mohammed Jameel (MBChB) ${ }^{1}$, Aseel Jasim Mohammed(MBChB,FICMS, P) ${ }^{2}$, \\ Sura Qais Almaaroff (MBChB, FICMS,CABP $)^{3}$ and Shefaa Mansour Hamza \\ $(\mathrm{MBChB}, \mathrm{FICMS}, \mathrm{P})^{4}$
}

\begin{abstract}
Background: Fifty percent of newborns may die because of neonatal sepsis who are not treated. The incidence augmented during the recent years. It may be due to the more public use of aggressiveprocesses and the growth of tough organisms.

Objective: To recognize factors (Ante - perinatal) that lead to sepsis (early or late) in newborn period in Albatool teaching hospital/Diyala/Iraq.

Patients and Methods: A case-control study done in the Department of Pediatrics in AlBatool Teaching Hospital, Diyala, Iraq during a period of seven months from Sept 2017 to April 2018. It comprised 200 neonates aged $\leq 28$ days. One-handered of them were presented to the hospital because of neonatal sepsis (case group) and the other 100 included neonates presented to the hospital because of other reasons (control group). A questionnaires were used to collect the essential information including demographic and clinical data for the neonates and their mothers.

Results: The mean age of neonates was $8.59 \pm 7.28$ days. Four factors were found to be noteworthy independent risk factors for neonatal sepsis. These factors were pre mature rupture membrane,presence or obscene odor discharge, intrapartum fever, and the prerequisite for resuscitation.

Conclusion: Both maternal and neonatal factors had contributed to the risk of neonatal sepsis. The onset of neonatal sepsis was higher in the first week of life.

Keywords: Newborn, sepsis, Iraq, risk factors.

Corresponding Author: as.jasim.lz@gmail.com

Received: $15^{\text {th }}$ January 2020

Accepted: $17^{\text {th }}$ May 2020

DOI:https://doi.org/10.26505/DJM.19015140115

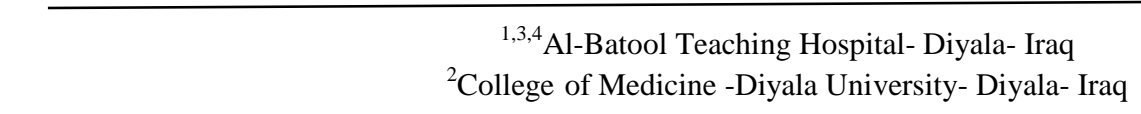

\section{Introduction}

Neonatal sepsis (NS) is a syndrome of an infant 28 days of life or younger, demonstrated by systemic signs of infection and separation of a bacterial pathogens from

the blood[1].Neonatal sepsis(NS) may cause around 3.1 million deaths each year [2,3]. Its incidence amplified during the recent years, it may be due to the further use of invasive
\end{abstract}


processes and the development of hardyorganisms [4].Remindful criteria of NS were: Fever $\left(\right.$ rectal $>38^{\circ} \mathrm{C}$ ), hypothermia (rectal $<36^{\circ} \mathrm{C}$ ), metabolic acidosis, WBC count $\geq 30,000 / \mathrm{mm}$ or $<5,000 / \mathrm{mm}$, or $>25 \%$ of immature cells, hypotension and lung symptoms [5]. According to the time and manner of infection, two types of NS can be distinguished: early onset sepsis, occurred during the first seven days of life or during the first 72 hours of life in very low birth weight infants [6] and Late-onset sepsis occurring after the first week of life [7,8].Group B streptococcus and E. coli together account for around $70 \%$ of conditions of early onset neonatal sepsis [9], while $70 \%$ of first incidentof late-onset infections were caused by gram-positive organisms, with coagulase-negative staphylococci accounting for about $48 \%$ of the infections, in addition to Listeria monocytogenes and Salmonella[10-15]. Both maternal and neonatal factors had subsidized to the risk of neonatal sepsis, as maternal UTI, residence of delivery, premature rupture membrane, intrapartum fever, low APGAR score at $5^{\text {th }}$ minute and not crying soon at birth. While Residence, parity, antenatal care service, mode of delivery, obscene smelling liquor, prematurity and low birth weight are recognized as possible independent risk factors of NS[12-19].Tests used to establish the diagnosis include blood, urine and CSF cultures, leukocyte profile, platelet count, ESR, C-reactive protein, latex agglutination tests, or counter immune electrophoresis, and polymerase chain reaction (PCR) [14-24].
Residual neurologic damage occurs in 15$30 \%$ of neonates with septic meningitis [16,17-28]. Aim of study to recognize factors (Ante - perinatal) that lead to sepsis (early or late) in newborn period in Albatool teaching hospital/Diyala/Iraq.

\section{Patients and Methods}

Study Design,setting and sample size: A case control study was carried out in the Department of Pediatrics in Al-Batool Teaching Hospital, Diyala Province, Iraq for the period from $1^{\text {st }}$ September 2017 to $30^{\text {th }}$ April 2018. It included 200 neonates $(\leq 28$ days) who were admitted to Al-Batool Teaching Hospital, 100 of them were presented to the hospital due to NS (cases) and the other 100 included neonates presented without neonatal sepsis (control). The haematological criteria plus the established IMNCI (Integrated Management of Neonatal and Childhood Illness) were used to diagnose NS. Newborns who were not fulfilled the criteria of sepsis and who were admitted to pediatric ward or NICU of AlBatool hospital were also encompassed with their index mothers as controls. Any newborn with congenital abnormality was excluded from this study. All patients were exposed to detailed history from the mother, full physical examination, and laboratory investigations include: (full Blood Count, CRP and blood culture). A well-structured questionnairewasdesigned to collect the essentialdata through interrogating the mothers and revisingnewborns medical records throughout the data gathering period. 


\section{Data of patients}

Age in days, gender, and weight in grams, gestational age, crying directly or not and requisite resuscitation or not), and maternal data included: (Age, residence whether it was rural areas or urban, learning level of mother: separated into Illiterate, primary school, secondary school and higher education), job (Housewife or employer), parity, diseases during pregnancy (Hypertension, bleeding disorder, PROM, and obsceneodor discharge), mode of delivery (NVD, C/S), place of delivery (Hospital, Home or health center), ANC attendance, intrapartum fever, and Per-vaginal examination $(<3 \mathrm{~cm}$ or $\geq 3$ $\mathrm{cm})$.

Ethical consent: The study protocol and the questionnaires were carried out according to principles of the Declaration of Helsinki, as well as revised and accepted by Ethics Research Committee of the College of medicine, university of Diyala. Verbal consents were also taken from the parents and caregivers of neonates involved in the study.

\section{Statistical analysis}

The data analyzed using Statistical Package for Social Sciences (SPSS) version 22. The data presented as mean, standard deviation and ranges. Categorical data presented by frequencies and percentages. Pearson's Chi-square test was used to measure statistical association between sepsis and different variables. Logistic regression analysis was applied using NS as the dependent variable and the variables that showed important association in the binary analysis as the independent variables. A level of $\mathrm{P}-$ value $<0.05$ was considered significant.

\section{Results}

The total number of newbornswho wereincluded in the study was 200; 50\% were diagnosed as sepsis (cases) and the other $50 \%$ with out neonatal sepsis (control). The mean age of the newborns was $8.59 \pm$ 7.28 days. The highest percentage of neonates with sepsis were aged $<7$ days (57.1\%) with a substantialrelationship ( $\mathrm{P}=$ $0.014)$ between age of newborns and sepsis. About $61.2 \%$ of neonates with birth weight < 2500 gms complained from NS with a statistically important association between neonatal birth weight and augmented prevalence of sepsis $(\mathrm{P}=0.025)$. It was found that peak proportion of neonates who required resuscitation complained from sepsis $(63.3 \%)$ with substantial association between resuscitation need of neonates and sepsis $(\mathrm{P}=0.001)$. There was insignificant relationship between sepsis and each of neonate's gender and abrupt crying $(\mathrm{P} \geq$ 0.05) as shown in Table 
Table (1): Relationship between NS and some neonatal variables

\begin{tabular}{|c|c|c|c|c|}
\hline \multirow[b]{2}{*}{ Neonatal Characteristics } & \multicolumn{2}{|c|}{ Study Group } & \multirow{2}{*}{$\begin{array}{c}\text { Total }(\%) \\
n=200\end{array}$} & \multirow[b]{2}{*}{ P - Value } \\
\hline & $\begin{array}{c}\text { Case Group (\%) } \\
(\mathrm{n}=100)\end{array}$ & $\begin{array}{c}\text { Control Group (\%) } \\
(\mathrm{n}=100)\end{array}$ & & \\
\hline \multicolumn{5}{|l|}{ Age (Days) } \\
\hline$<7$ & 68 (57.1) & $51(42.9)$ & $119(59.5)$ & \multirow{2}{*}{0.014} \\
\hline $7-28$ & $32(39.5)$ & $49(60.5)$ & $81(40.5)$ & \\
\hline \multicolumn{5}{|l|}{ Gender } \\
\hline Male & $63(53.4)$ & $55(46.6)$ & $118(59.0)$ & \multirow{2}{*}{0.25} \\
\hline Female & $37(45.1)$ & $45(54.9)$ & $82(41.0)$ & \\
\hline \multicolumn{5}{|l|}{ Birth Weight (gms) } \\
\hline$<2500$ & $41(61.2)$ & $26(38.8)$ & $67(33.5)$ & \multirow{2}{*}{0.025} \\
\hline$\geq 2500$ & $59(44.4)$ & $74(55.6)$ & $133(66.5)$ & \\
\hline \multicolumn{5}{|l|}{ Immediate Crying } \\
\hline Yes & $84(48.6)$ & $89(51.4)$ & $173(86.5)$ & \multirow{2}{*}{0.301} \\
\hline No & $16(59.3)$ & $11(40.7)$ & $27(13.5)$ & \\
\hline \multicolumn{5}{|l|}{ Need Resuscitation } \\
\hline $\begin{array}{c}\text { Yes } \\
\end{array}$ & $62(63.3)$ & $36(36.7)$ & $98(49.0)$ & \multirow{2}{*}{0.001} \\
\hline No & $38(37.3)$ & $64(62.7)$ & $102(51.0)$ & \\
\hline
\end{tabular}

There was insignificant relationship between general features of their mothers $(\mathrm{P} \geq 0.05)$ as prevalence of sepsis in neonates and all of the shown in Table (2).

Table (2): Relationship between NS and general features of study group's mothers

\begin{tabular}{|c|c|c|c|c|}
\hline \multirow[b]{2}{*}{ Maternal Characteristics } & \multicolumn{2}{|c|}{ Study group } & \multirow{2}{*}{$\begin{array}{c}\text { Total }(\%) \\
\mathrm{n}=200\end{array}$} & \multirow[b]{2}{*}{$\mathrm{P}$ - value } \\
\hline & $\begin{array}{c}\text { Case group (\%) } \\
\mathrm{n}=100\end{array}$ & $\begin{array}{c}\text { Control group (\%) } \\
n=100\end{array}$ & & \\
\hline \multicolumn{5}{|l|}{ Maternal age (years) } \\
\hline$<21$ & $15(45.5)$ & $18(54.5)$ & $33(16.5)$ & \multirow{3}{*}{0.274} \\
\hline $21-34$ & $66(48.2)$ & $71(51.8)$ & $137(68.5)$ & \\
\hline$\geq 35$ & $19(63.3)$ & $11(36.7)$ & $30(15.0)$ & \\
\hline \multicolumn{5}{|l|}{ Residence } \\
\hline Urban & $42(46.2)$ & $49(53.8)$ & $91(45.5)$ & \multirow{2}{*}{0.32} \\
\hline Rural & $58(53.2)$ & $51(46.8)$ & $109(54.5)$ & \\
\hline \multicolumn{5}{|l|}{ Education } \\
\hline Illiteracy & 17 (48.6) & $18(51.4)$ & $35(17.5)$ & \multirow{4}{*}{0.504} \\
\hline Primary school & $55(53.9)$ & $47(46.1)$ & $102(51.0)$ & \\
\hline Secondary school & 11 (37.9) & $18(62.1)$ & 29 (14.5) & \\
\hline Higher education & $17(50.0)$ & $17(50.0)$ & $34(17.0)$ & \\
\hline \multicolumn{5}{|l|}{ Occupation } \\
\hline Housewife & $92(49.2)$ & $95(50.8)$ & $187(93.5)$ & \multirow{3}{*}{0.449} \\
\hline Employer & $7(63.6)$ & $4(36.4)$ & $11(5.5)$ & \\
\hline Student & $1(50.0)$ & $1(50.0)$ & $2(1.0)$ & \\
\hline
\end{tabular}


The relationship between NS and certain diseases during pregnancy is shown in Table (3). There is a peak proportion of mothers who complained from (UTI/STD, PROM, and presence or obscene of odor discharge during pregnancy and neonates complaining from sepsis $(56.3 \%, 90.3 \%$, and $77.8 \%$ respectively $) \quad(\mathrm{P}=0.005, \quad \mathrm{P}=0.001, \quad$ and $\mathrm{P}=0.001$ respectively).

Table (3): The relationship betweenNS and somediseases during pregnancy

\begin{tabular}{|c|c|c|c|c|}
\hline \multirow[b]{2}{*}{ Variable } & \multicolumn{2}{|c|}{ Study group } & \multirow[b]{2}{*}{$\begin{array}{c}\text { Total }(\%) \\
n=200\end{array}$} & \multirow[b]{2}{*}{$\mathrm{P}$ - value } \\
\hline & $\begin{array}{c}\text { Case group (\%) } \\
n=100\end{array}$ & $\begin{array}{c}\text { Control group }(\%) \\
n=100\end{array}$ & & \\
\hline \multicolumn{5}{|l|}{ Hypertension } \\
\hline Yes & $17(60.7)$ & $11(39.3)$ & $28(14.0)$ & \multirow{2}{*}{0.221} \\
\hline No & $83(48.3)$ & $89(51.7)$ & $172(86.0)$ & \\
\hline \multicolumn{5}{|l|}{ Bleeding disorders } \\
\hline Yes & $11(73.3)$ & $4(26.7)$ & $15(7.5)$ & \multirow{2}{*}{0.06} \\
\hline No & $89(48.1)$ & $96(51.9)$ & $185(92.5)$ & \\
\hline \multicolumn{5}{|l|}{ UTI or STD } \\
\hline Yes & $81(56.3)$ & $63(43.8)$ & $144(72.0)$ & \multirow{2}{*}{0.005} \\
\hline No & $19(33.9)$ & $37(66.1)$ & $56(18.0)$ & \\
\hline \multicolumn{5}{|l|}{ PROM $>18$} \\
\hline Yes & $28(90.3)$ & $3(9.7)$ & $31(15.5)$ & \multirow{2}{*}{0.001} \\
\hline No & $72(42.6)$ & $97(57.4)$ & $169(84.5)$ & \\
\hline \multicolumn{5}{|c|}{ Foul smelling discharge } \\
\hline Yes & $49(77.8)$ & $14(22.2)$ & $63(31.5)$ & \multirow{2}{*}{0.001} \\
\hline No & $51(37.2)$ & $86(62.8)$ & $137(68.5)$ & \\
\hline
\end{tabular}

Table (4) shows the relationship between NS and some obstetrical data. We observed that $72.1 \%$ of mothers with GA $<37$ weeks had neonates complained from sepsis with a statistically noteworthyrelationship between augmented prevalence of sepsis and GA
$(\mathrm{P}=0.003)$. Multiparous mothers (more than five), had a significant association between NS and parity $(\mathrm{P}=0.046)$.Intrapartum fever during pregnancy, had a significant association withNS $(\mathrm{P}=0.001)$. 
Table (4): The relationship betweenNS and some obstetrical data

\begin{tabular}{|c|c|c|c|c|}
\hline \multirow[b]{2}{*}{ Variable } & \multicolumn{2}{|c|}{ Study group } & \multirow{2}{*}{$\begin{array}{c}\text { Total }(\%) \\
n=200\end{array}$} & \multirow[b]{2}{*}{$\mathrm{P}$ - value } \\
\hline & $\begin{array}{c}\text { Case group (\%) } \\
\mathrm{n}=100\end{array}$ & $\begin{array}{c}\text { Control group (\%) } \\
n=100\end{array}$ & & \\
\hline \multicolumn{5}{|l|}{ Gestational age } \\
\hline$<37$ week & $31(72.1)$ & $12(27.9)$ & $43(21.5)$ & \multirow{3}{*}{0.003} \\
\hline 37 - 42 week & 68 (43.6) & $88(56.4)$ & $156(78.0)$ & \\
\hline$>42$ week & $1(100.0)$ & $0(0)$ & $1(0.5)$ & \\
\hline \multicolumn{5}{|l|}{ Mode of delivery } \\
\hline NVD & $48(51.1)$ & $46(48.9)$ & $94(47.0)$ & \multirow{2}{*}{0.777} \\
\hline $\mathrm{C} / \mathrm{S}$ & $52(49.1)$ & 54 (50.9) & $106(53.0)$ & \\
\hline \multicolumn{5}{|l|}{ Place of delivery } \\
\hline Home & $12(42.9)$ & $16(57.1)$ & $28(14.0)$ & \multirow{2}{*}{0.415} \\
\hline Hospital & 88 (51.2) & $84(48.8)$ & $172(86.0)$ & \\
\hline \multicolumn{5}{|l|}{ Parity } \\
\hline 1 & $31(56.4)$ & $24(43.6)$ & $55(27.5)$ & \multirow{3}{*}{0.046} \\
\hline $2-4$ & $44(41.9)$ & $61(58.1)$ & $105(52.5)$ & \\
\hline$\geq 5$ & $25(62.5)$ & $15(37.5)$ & $40(20.0)$ & \\
\hline \multicolumn{5}{|l|}{ ANC } \\
\hline Yes & $93(50.0)$ & $93(50.0)$ & $186(93.0)$ & \multirow{2}{*}{1.0} \\
\hline No & $7(50.0)$ & $7(50.0)$ & $14(7.0)$ & \\
\hline \multicolumn{5}{|l|}{ Intrapartum fever } \\
\hline $\begin{array}{c}\text { Yes } \\
\end{array}$ & $47(78.3)$ & $13(21.7)$ & $60(30.0)$ & \multirow{2}{*}{0.001} \\
\hline No & $53(37.9)$ & $87(62.1)$ & $140(70.0)$ & \\
\hline \multicolumn{5}{|c|}{ Per vaginal examination } \\
\hline Yes & $57(54.3)$ & $48(45.7)$ & $105(52.5)$ & \multirow{2}{*}{0.131} \\
\hline No & $41(44.1)$ & $52(55.9)$ & $93(46.5)$ & \\
\hline
\end{tabular}

Logistic regression analysis was applied in association in the binary analysis as the Table (5) using NS as a dependent variable independent variables. and the variables that showed significant

Table (4): Logistic regression analysis for relationship of different risk factors with NS

\begin{tabular}{|c||c||c||c||c||}
\hline \multirow{2}{*}{ Factors } & \multirow{2}{*}{ Odds ratio } & \multicolumn{2}{c|}{ 95\% C.I. } & \multirow{2}{*}{ P- value } \\
\cline { 3 - 4 } & & lower & upper & \\
\hline \hline PROM & 12.241 & 3.160 & 47.418 & 0.001 \\
\hline \hline Foul smelling discharge & 4.705 & 2.037 & 10.868 & 0.001 \\
\hline \hline Intrapartum fever & 3.452 & 1.476 & 8.073 & 0.004 \\
\hline \hline Need Resuscitation & 2.607 & 1.183 & 5.745 & 0.017 \\
\hline
\end{tabular}




\section{Discussion}

Epidemiological statistics from developing states shows significantvariancein the incidence and risk factors [17]. Despite major improvements in researches in developed countries, $40 \%$ of infants with sepsis die or had a neurodevelopmental injury[18].In this study, four important independent risk factors for NS and these factors were PROM, presence of obsceneodor discharge, intrapartum fever, and the requisite for resuscitation which is consistent to an Ethiopian study (2015) [12]. Diverse risk factors detected in Mexico (2014), when only low birth weight, prematurity, abnormal amniotic fluid and any lung complication were recognized as independent risk factors for sepsis[19]. Egyptian study in 2016 noted the peak effect on sepsis was PROM, twin deliveries, multipara mothers and normal vaginal delivery [20]. Lastly, postnatal age and parity are independent risk factors for NS in Chinese study in 2017 [21]. These variances are multifactorial, as the gaps in public services in terms of skilled health staff, supply of crucial drugs, tools, localalterations in bacterial strains and logistics analysis of factors affecting sepsis [22].Neonatal birth weight dropsas a significant risk factor for sepsis 2.75 times greater than normal babies in an Indonesian study in 2010, [23], and in Nepal (2006) [24]. Moreover, American study in 2002 found that late-onset sepsis was asignificant risk factor for death amongst very low birth weight infants [25]. This may be explained by fact that somewhat immunodeficiency condition in the premature and low birth weight infant susceptible to the sepsis condition, as a results of invasive processes for diagnostic and therapeutic purposes [24]. Urinary tract infection or sexually transmitted illness had a significant relationship with sepsis in an Ethiopian study in 2015 [12] and in India (2005) [26], Ghana (2014) [27] and Ethiopia (2014) [28].These might be elucidated by sepsis following the colonization of the birth canal by the infectious agent. In this study, PROM was expressively related to sepsis, in line to another studies in USA (2014)[29], in India (2011) [30], in Nepal (2006)(24), in Pakistan (2014)[31] and a Romania (2010)[32]. But in contrary to that in Saudi Arabia (2002), where insignificant role was described[33]. Early PROM upsurges the chance of ascending microorganisms from the birth canal into the amniotic sac and fetal compromise as well as asphyxia which leads to sepsis [26]. Lastly, Intrapartum fever in this study was meaningfullyconnected to sepsis, in consistent to that in Ethiopia (2015)(25), in Pakistan (2014)[34]and Bangladesh (2011)[31]. This is clarified by the fact that intrapartum fever is suggestive of maternal infections that are habitually transmitted to the baby in utero or during passage through the canal which usually causes early onset sepsis [35].

\section{Conclusions}

This study found that both maternal and neonatal factors had contributed to the risk of 
NS, and the onset of NS was higher in the first week of neonate's life.

\section{Recommendations}

According to the conclusions of the current study, it is recommended that universal screening for rectovaginal GBS colonization of all pregnant women at 35-37 week gestation \&screening based approach to selected intrapartum antibiotic prophylaxis for GBS.

\section{References}

[1]Edwards MS., Baker CJ. Sepsis in the newborn. In: Gershon A. A., Hotez P. J., Katz S. L., editors. Krugman's Infectious Diseases of Children. Philadelphia, Pa, USA: Mosby2004. p. p. 545.

[2]UNICEF. Levels and Trends in Child Mortality. New York, NY, USA: UNICEF; 2011.

[3]Ferreira RC, Mello RR, Silva KS. Neonatal sepsis as a risk factor for neurodevelopmental changes in preterm infants with very low birth weight. Jornal de Pediatria 2014;90(3):293-299.

[4]Glodstein B, Giroir B, Randolph A. International pediatric sepsis consensus conference: definitions for sepsis and organ dysfunction in pediatrics. Pediatric Critical Care Medicine2005 1;6(1):99.

[5]Khassawneh M, Khader Y, Abuqtaish N. Clinical features of neonatal sepsis caused by resistant Gram-negative bacteria. Pediatrics International 2009.

[6]Mukhopadhyay S, Puopolo KM. Risk assessment in neonatal early onset sepsis. In Seminars in perinatology 20121 (Vol. 36, No. 6,. 408-415). WB Saunders.
[7]Camacho-Gonzalez, P.W. Spearman, B.J. Stoll Neonatal infectious diseases: evaluation of neonatal sepsis PediatrClin North Am 60 (2013),. 367-389.

[8]Chan GJ, Lee AC, Baqui AH, Tan J, Black RE. Risk of early-onset neonatal infection with maternal infection or colonization: a global systematic review and meta-analysis. PLoS medicine 2013 20;10(8): e1001502.

[9]Bizzarro MJ, Raskind C, Baltimore RS, Gallagher PG. Seventy-five years of neonatal sepsis at Yale: 1928-2003. Pediatrics 2005; 116:595-602.

[10]Hansen N, Stoll BJ, Fanaroff AA, Wright LL, Carlo WA, Ehrenkranz RA, et al. Lateonset sepsis in very low birth weight neonates: the experience of the NICHD Neonatal Research Network. Pediatrics 2002; 110:285-91.

[11]Rawat S, Neeraj K, Preeti K, Prashant M. A review on type, etiological factors, definition, clinical features, diagnosis management and prevention of neonatal sepsis. Journal of scientific and innovative research 2013;2(4):802-13.

[12]Gebremedhin D, Berhe H, Gebrekirstos $\mathrm{K}$. Risk factors for neonatal sepsis in public hospitals of Mekelle City, North Ethiopia, 2015: unmatched case control study. PloS one. 2016 10;11(5): e0154798.

[13]Mclntosh N, Stenson B. Neonatal infection. In: McIntosh N, Helms P, SmythR (eds). Forfar and Arneil textbook of pediatrics. $7^{\text {th }}$ ed. Philadelphia. Churchill Livingstone CO 2008: 274-275. 
[14]Ahmed Z, Ghafoor T, Waqar T, et al. Diagnostics value of $\mathrm{C}$-reactive protein and hematological parameters in neonatal sepsis. J Coll Physician Surgpak 2005; 15(3): 152156.

[15]Zaidi AK, Huskins WC, ThaverD,. Hospital-acquired neonatal infections in developing countries. Lancet 2005; 365:1175-1188.

[16]Anderson-Berry AL., Rosenkrantz T. Cardiac Disease and Critical Care Medicine, Neonatal Sepsis, Updated: Dec 31, 2015. https://emedicine.medscape.com/article/9783 52-overview\#a7

[17]Hornik CP, Fort P, Clark RH, Watt K, Benjamin DK, Smith PB, et al. Early and late onset sepsis in very-low-birth-weight infants from a large group of neonatal intensive care units. Early Hum Dev. 2012;88 2): S69-74. [18]Brocklehurst P, Farrell B, King A, Juszczak E, Darlow B, Haque K, et al. Treatment of neonatal sepsis with intravenous immune globulin. The New England journal of medicine. 2011;365(13):1201-11.

[19]Leal YA, Álvarez-Nemegyei J, Velázquez JR, Rosado-Quiab U, DiegoRodríguez N, Paz-Baeza E, et al. Risk factors and prognosis for neonatal sepsis in southeastern Mexico: analysis of a four-year historic cohort follow-up. BMC pregnancy and childbirth. 2012;12(1):48.

[20]Medhat H, Khashana A, El Kalioby M. Multivariate Logistic Regression Analysis for the Significant Neonatal and Maternal Risk Factors Related to Neonatal Sepsis, Int J Infect. 2016 ;3(4):e38290.
[21]Xiao T, Chen LP, Liu H, Xie S, Luo Y, $\mathrm{Wu} \mathrm{DC}$. The analysis of etiology and risk factors for 192 cases of neonatal sepsis. BioMed research international 2017;2017. [22] Chowdhury S, Hossain SA, Halim A. Assessment of quality of care in maternal and newborn health services available in public health care facilities in Bangladesh. Bangladesh Medical Research Council Bulletin 2009;35(2):53-6..

[23]Utomo MT. Risk factors of neonatal sepsis: a preliminary study in Dr. Soetomo hospital. Indonesian journal of tropical and infectious disease 2010 1;1(1):23-6.

[24]Shah GS, Budhathoki S, Das BK, Mandal RN. Risk factors in early neonatal sepsis. Kathmandu University medical journal (KUMJ) 2006;4(2):187-91.

[25]Stoll BJ, Hansen N, Fanaroff AA, Wright LL, Carlo WA, Ehrenkranz RA, et al. Lateonset sepsis in very low birth weight neonates: the experience of the NICHD Neonatal Research Network. Pediatrics 2002 1;110(2):285-91.

[26]Siakwa M, Kpikpitse, Mupepi D, Mohamed SS. Neonatal sepsis in rural Ghana: A case control study of risk factors in a birth cohort. IJRMHS \& K.A.J2014; 4(5) 77-88.

[27]Woldu MA, Guta MB, Lenjisa JL, Tegegne GT, Tesafye G, Dinsa H. Assessment of the incidence of neonatal sepsis, its risk factors, antimicrobial use and clinical outcomes in Bishoftu General Hospital, Neonatal Intensive Care Unit, Debrezeit-Ethiopia. Pediat Therapeut 2014; 4: 214. 
[28]Chacko B, Sohi I. Early onset neonatal sepsis. Indian J Pediatr2005; 72(1):23-26.

[29]Gyamfi-Bannerman C, Son M. Preterm premature rupture of membranes and the rate of neonatal sepsis after two courses of antenatal corticosteroids. Obstetrics \& Gynecology 2014 1;124(5):999-1003.

[30]Bhat R, Lewis LE, Vandana KE. Bacterial isolates of early-onset neonatal sepsis and their antibiotic susceptibility pattern between 1998 and 2004: an audit from a center in India. Italian journal of pediatrics 2011;37(1):32.

[31]Alam MM, Saleem AF, Shaikh AS, Munir O, Qadir M. Neonatal sepsis following prolonged rupture of membranes in a tertiary care hospital in Karachi, Pakistan. The Journal of Infection in Developing Countries. 2014 15;8(01):067-73.

[32]Boia M, Ilie C, Ioanas L, Manea A, Iacob D, Cioboata D. Neonatal septicemia retrospective study on premature newborn. JurnalulPediatrului 2010; 8:49-50.

[33]Asindi AA, Archibong EI, Mannan NB. Mother-infant colonization and neonatal sepsis in prelabor rupture of membranes. Saudi Med J 2002; 23(10): 1270-4.

[34]Hasan MS, Mahmood CB. Predictive values of risk factors in neonatal sepsis. J Bangladesh CollPhysSurg 2011; 29: 187195.

[35]Soman M, Green B, Daling J. Risk factors for early onset neonatal sepsis. Am.J. Epidemiol (1985) 121 (5): 712-719. 